\title{
Protecting Natural Capital Through Ecosystem Service Districts
}

\author{
Geoffrey Heal,* Gretchen C. Daily, *:: \\ Paul R. Ehrlich, ** James Salzman, ***: Carol Boggs, ;:* \\ Jessica Hellmann, **: Jennifer Hughes, $* *$ \\ Claire Kremen, $* *$ Taylor Ricketts $* *$
}

I. IntRoDUCTION $\ldots \ldots \ldots \ldots \ldots \ldots \ldots \ldots \ldots \ldots \ldots \ldots \ldots \ldots \ldots, 334$

II. Threats to ECOSYSTEM SERVICES ................. 336

A. What Are Ecosystem Services? ............... 336

B. Why Should We Care About Ecosystem Services?. 338

C. Why Are Services Under Threat? ............. 340

D. To What Extent Do Our Institutions Protect

Ecosystem Services? ....................... 342

III. AN Ecological Economic Framework........... 343

A. A Hypothetical District ....................... 343

B. Modeling Tradeoffs ........................ 345

C. The Optimal Output ...................... 352

IV. Legal Analysis of Managing Ecosystem Services

Districts................................ 353

V. Priortries for Putting Theory of Ecosystem Service Districts into Practice ................. 357

A. Characterizing the Production Functions of

Ecosystem Services ...................... 357

B. Mapping Ecosystem Services................ 358

C. Transitioning Toward a System of Ecosystem

Service Districts ........................... 360

VI. Conclusion ................................ 361

\footnotetext{
* Garrett Professor of Public Policy and Business Responsibility, Graduate School of Business, Columbia University.

$* *$ Center for Conservation Biology, Stanford University.

**** Professor, Washington College of Law, American University. This work was supported, in part, by the United States Environmental Protection Agency's (EPA's) Science to Achieve Results (STAR) program grant R82612-01. Because this article has not been subjected to any EPA review and does not necessarily reflect the views of the Agency, no official endorsement should be inferred.
} 


\section{INTRODUCTION}

Societies invest a great deal of effort in monitoring and cultivating their physical, financial, and human capital. By comparison, they typically pay scant attention to their natural capital, especially that embodied in ecosystems. ${ }^{1}$ Ecosystems are capital assets: if properly managed, ecosystems supply a stream of critical life-support services. These "ecosystem services" include the production of goods (such as seafood and timber), life support processes (such as pollination, flood control, and water purification), and life-fulfilling conditions (such as beauty and serenity), as well as the conservation of options for the future (such as genetic diversity). ${ }^{2}$

Specialized governmental institutions do, of course, pay attention to some of these services, but their focus is primarily on the provision of services through modification of the landscape or construction of specialized facilities-that is, through "built structures." For example, local officials have historically built dikes and levees to minimize flood damage in the United States rather than provide the same service through protecting or restoring wetlands. Water suppliers have generally built purification plants rather than restore forested watersheds. In some cases, built provision of services will prove an optimal strategy, providing greater social benefits at a lower cost. We argue that in many instances, however, the net value of the joint products yielded by ecosystems will exceed that of built structures. The joint products of a wetland, for instance, may include flood control, water purification, recreation, scenic beauty, and habitat conservation. Yet with rare exception, local, state, and national governments simply do not consider ecosystems as valuable providers of services. Without explicit comparisons between natural and built provision of services, we will continue to miss opportunities where reliance on natural capital provides the lowest cost services for human welfare.

This issue of the Stanford Environmental Law Journal explores the implications of a broad shift in environmental law toward explicit protection of ecosystem services. In this article, we focus on the

1. Natural capital has two major components: non-renewable stocks of natural resources (e.g., fossil fuels and other minerals) and renewable stocks embodied in ecosystems. See generally Investing in Natural Capital: The Ecological Economics Approacu to Sustajnability (Ann Mari Jansson et al. eds., 1994) (explaining the economic value of natural capital) [hereinafter INVESTING IN NATURAL CAPITAL].

2. See Gretchen C. Daily et al., The Value of Nature and the Nature of Value, 289 SciENCE 395, 395-96 (2000). 
potential for creating governmental authorities dedicated to the management and protection of ecosystem services. We argue that the creation of what we call Ecosystem Service Districts (ESDs) will efficiently provide many of the services necessary for human welfare and additional benefits, as well.

Thousands of districts for soil conservation, resource conservation, flood control, and other local services are currently found across the United States. There are 2,935 soil conservation districts alone (encompassing 3,209 counties). ${ }^{3}$ In some instances, these districts have been provided with significant legal authority, including the powers of taxation, eminent domain, and zoning. They do not, however, generally consider ecosystems as providers of services. Flood control, for example, is managed at three different levels: nationally by the Bureau of Reclamation, regionally by interstate compacts, and within states by local flood districts. With rare exception, these institutions all carry the same toolkit, with three construction tools-dikes, dams, and levees-but no ecosystem service tools for assuring flood prevention. ${ }^{4}$ These districts do, however, provide an instructive starting point for the development of ESDs.

In order to manage ESDs wisely, we need to ensure a careful comparison of the different means of providing services. Explicit consideration of ecosystem services, even with imperfect understanding, will make it possible to maximize our investments in service provision. For example, New York City was faced with the task of restoring its drinking water to levels that satisfied EPA standards. ${ }^{5}$ The City chose to restore natural water purification services in the Catskills watershed at a cost of roughly $\$ 1.5$ billion in lieu of constructing a much more expensive water filtration plant. This amounts to an investment in natural capital rather than physical capital on economic grounds. New York City taxpayers will receive clean water at the lowest overall cost; stewards of the watershed (in the Catskill Mountains, about one hundred miles away from New York City) will be compensated for the purification services they provide to the City; and other services supplied by the Catskills

3. John B. Braden \& Donald L. Uchtmann, Soil Conservation Programs Atnidss Fallering Environmental Commitments and the "New Federalism, 10 B.C. Evrt. Afr. L. REv. 639, 642 n.II (1982) (citing U.S. DeP'T OF AGR., SOIL \& W'ATER RES. CONSERvition ACt 1980 Ap. praisal Review Draft Part II, ch. 7 at 26 (1980)).

4. James Salzman, Barton H. Thompson, Jr., \& Gretchen C. Daily, Protecting Eresystem Services: Science, Economics, and Law, 20 STAN. ENvT. LJ. 309, 320-21 (2001).

5. Id. at 315 . 
ecosystem (e.g., carbon storage, aesthetic and recreational benefits, cultural preservation) will be better protected under the umbrella of water purification.

Establishing ESDs could provide an institutional mechanism to help ensure that natural capital is protected and maintained with the same care and concern as that given to built and human capital. But establishing and managing ESDs requires a clear understanding of the underlying ecological processes that provide the services, the economic significance of the services, and the legal issues involved in managing natural ecosystems for the good of a local or regional community.

In this article, we use ecological, economic, and legal analyses to create a conceptual framework for managing patterns of land use in districts of varying sizes that could provide different ecosystem services and also support different, and potentially conflicting, types of economic activity. Part II of the article explains why ecosystem services are under threat and describes the potential benefits of managing their conservation through ESDs. Part III lays out the basic ecological-economic framework and principles for district design. Part IV sets out the key legal issues involved in the creation and management of ESDs, and Part V presents a roadmap for putting theory into practice.

\section{ThreAtS TO ECOSYSTEM SERVICES}

This section explains the importance of ecosystem services and why, despite their importance, they are not generally valued by markets or given greater protection by the law.

\section{A. What Are Ecosystem Services?}

Ecosystem services are defined as "the conditions and processes through which natural ecosystems, and the species that make them up, sustain and fulfill human life." An ecosystem is the array of organisms-plants, animals, and microbes-found in a defined area and the physico-chemical environment with which that living community interacts. Ecosystems are a key part of our "natural capital." Just as human and human-made capital supply a stream of benefits, natural capital supplies a stream of goods and other life-

6. Gretchen C. Daily, Introduction: What Are Ecosystem Services? in NatuRE's SERvices: Societal Dependence on Natural Ecosystems 3 (Gretchen C. Daily ed., 1997).

7. See generally INVEsting in Natural Capital, supra note 1 . 
support services, many of which are identified in Table 1 , below: 8 Ecosystems deliver these societal benefits "for free" and, in many cases, on a scale so large that humanity would find it practically impossible to substitute for them. ${ }^{9}$

TABLE 1. Ecosystem services. ${ }^{10}$

\begin{tabular}{|c|c|}
\hline Production of Goods & Regeneration Processes \\
\hline Food & Gjcling and filtration processes \\
\hline $\begin{array}{l}\text { terrestrial animal and plant products } \\
\text { such as cereals, fruits and vegetables, } \\
\text { forage, seafood, spice }\end{array}$ & $\begin{array}{l}\text { detoxification and decomposition of } \\
\text { wastes }\end{array}$ \\
\hline Pharmaceuticals & generation and renewal of soil fertility \\
\hline natural medicinal products & purification of air and water \\
\hline precursors to synthetic pharmaceuticals & Translocation processes \\
\hline Durable materials & $\begin{array}{l}\text { dispersal of seeds necessany for } \\
\text { revegetation }\end{array}$ \\
\hline timber & $\begin{array}{l}\text { pollination of crops and natural } \\
\text { vegetation }\end{array}$ \\
\hline \multicolumn{2}{|l|}{ rattan, cotton, etc. } \\
\hline Energy & Stabiujzing Processes \\
\hline biomass fuels & coastal and river channel stability \\
\hline low-sediment water for hydropower & $\begin{array}{l}\text { control of the majority of potential } \\
\text { pest species }\end{array}$ \\
\hline Industrial products & moderation of weather extremes \\
\hline $\begin{array}{l}\text { waxes, oils, fragrances, dyes, latex, } \\
\text { rubber, etc. }\end{array}$ & partial stabilization of climate \\
\hline precursors to many synthetic products & mitigation of floods and droughts \\
\hline \multicolumn{2}{|l|}{ Biodiversity } \\
\hline genetic resources & LIFE-FuIfHIING FunctIONS \\
\hline $\begin{array}{l}\text { intermediate goods that enhance the } \\
\text { production of other goods }\end{array}$ & $\begin{array}{l}\text { existence value; provision of cultural, } \\
\text { intellectual, and spiritual inspiration }\end{array}$ \\
\hline
\end{tabular}

Ecosystem services are generated by a complex of natural cycles, driven by solar energy, that constitute the workings of the biosphere-the relatively thin layer around Earth's surface that contains all known life. These cycles are ancient, the product of

8. See generally Gretchen C. Daily, Dereloping a Scientific Basis for Managing Eanth's LifeSupport Systems, 3 Conservation Ecology 14 (1999), at http://wrw.consecol.org/vol3/ iss2/artl4 (last visited May 2, 2001).

9. See Paul R. Ehrlich \& Harold A Mooney, Extinction, Substitution and Erosystems Services, 33 BIoScIENCE 248 (1983).

10. Adapted from Daily, supra note 8. 
billions of years of evolution, and have existed in forms very similar to those seen today for at least hundreds of millions of years. They are absolutely pervasive, but unnoticed by most human beings going about their daily lives.

\section{B. Why Should We Care About Ecosystem Services?}

Natural cycles, though taken for granted, provide the basis for human existence. If, for instance, natural pest control services ceased-for example, if the life cycles of natural pest enemies were altered, or if natural enemies were eliminated in some areasthere could be disastrous crop failures. ${ }^{11}$ If populations of bees and other pollinators crashed, society could face similar dire consequences. ${ }^{12}$ If the carbon cycle were badly disrupted, rapid climatic change could threaten whole societies. ${ }^{13}$

An example from a decade ago in the Arizona desert well illustrates our dependency on functioning ecosystems and the consequences of loss of those systems. ${ }^{14}$ In 1991, a giant greenhouse was built covering 3.15 acres. Called Biosphere 2 (to differentiate it from Biosphere 1, in which we are all living now), the greenhouse was intended to be hermetically sealed and, within, various sections would recreate mini-ecosystems. There were grasslands, marshlands, an ocean (including a coral reef), and even a tropical rainforest (each with representative flora and fauna); a fairly large portion of Biosphere 2 was devoted to intensive agriculture. The whole system was designed to support eight human beings, aptly known as "Biospherians."

In mid-1991, four men and four women were sealed into Biosphere 2 to stay for two years. The situation deteriorated rapidly.

11. See Rosamond L. Naylor \& Paul R. Ehrlich, Natural Pest Control Services and Agriculture, in Nature's Services: Societal Dependence on Natural Ecosystems 151 (Gretchen C. Daily ed., 1997). (1996).

12. See Stephen L. Buchmann \& Gary Paul Nabhan, The Forgotten Pollinators

13. As just one example, consider the large number of "environmental refugees" that would be created if the sea level rises by several feet, flooding or submerging low island states and coastal areas of developing countries. See Norman Myers \& Jennifer Kent, ENVI. RONMENTAL Exodus (1995); Third Assessment Report of Working Group I, Intergovernmental Panel on Climate Change, United Nations Framework Convention on Climate Change (2001) [hereinafter WGI TAR]; Summary for Poligy Makers, at http://www.meto.gov.uk/ sec5/CR_div/ipcc/wgl/ipcctar.html (last visited May 2, 2001).

14. See Biosphere 2: Research Past and Present (B.D.V. Marino \& H.T. Odum. eds., 1999); Columbia University's Biosphere 2 Center, at http://www.bio2.edu (last visited April 25, 2001); see also James Salzman, Valuing Ecosystem Services, 24 Ecolocy. L.Q. 887, 888 (1997) (citing additional sources). 
One after another, the ecosystems collapsed and ceased providing their essential services. Oxygen concentrations in the atmosphere dropped to levels normally found at 17,500 feet elevation; nitrous oxide concentrations spiked upward to the point of impairing brain function, and carbon dioxide levels fluctuated erratically.

The Biosphere experiment was disastrous. Nineteen of twentyfour vertebrate species went extinct almost immediately, as did all of the pollinators. The loss of pollinators made reproduction of many plants impossible and limited their persistence to the lifetimes of the original individual plants. Natural pest control services failed: ants swarmed everywhere; cockroaches and katydids flourished. Morning glories and other vines that had been added to the experiment to absorb excess carbon dioxide ran rampant. The Biospherians strove to weed them out, but their efforts fell short and their crops were overgrown by these species. The occupants were starving and in desperation decided to cut down their tropical rainforest in order to plant more food crops. They also sneaked in candy bars and other rations from Biosphere 1, and there were tales of considerable friction among the Biospherians as food supplies dwindled.

Moreover, the aquatic systems-the source of irrigation and drinking water-accumulated excess nutrients, which had to be removed by growing and harvesting by hand large mats of algae. A planned brackish estuary had to be permanently isolated from the "ocean" because of problems in managing its water chemistry. Huge amounts of electricity, at a cost of about $\$ 1$ million each year, were required to supplement the solar energy.

Despite its failures, the Biosphere 2 experiment taught us four important lessons: ${ }^{15}$

- the crucial importance of ecosystem services;

- how little we know about maintaining them;

- the possibly severe consequences of disrupting them;

- and the need for great caution where human impacts threaten ecosystem services.

Biosphere 1 is much larger, better "tested and designed," and thus more resilient than Biosphere 2. Nonetheless, there are many signs that its ecosystem services are faltering, including increasingly extreme weather and other climatic problems, ${ }^{16}$ deterioration of the

15. Joel E. Cohen \& David Tilman, Biosphere 2 and Biodiversily: Leasons So Far, 274 SCIENCE 1150, 1150-51 (1996).

16. See Stephen H. Schneider, Laboratory Earth: The Planetary G.luble We Glv't AfFoRd to LOSE (1997); WGI TAR, supra note 13. 
ozone layer, ${ }^{17}$ increased problems with pest control, ${ }^{18}$ declines in pollinator populations, ${ }^{19}$ the collapse of oceanic fisheries, ${ }^{20}$ and the general decay of biodiversity. ${ }^{21}$

\section{Why Are Services Under Threat?}

Ecosystem services are threatened for two basic reasons. The first is that the scale of the human enterprise is now so large that humanity is drastically altering natural ecosystems and the processes they control. ${ }^{22}$ For millennia, human impacts were typically local, minor, and reversible. Today, human influence can be discerned in the most remote reaches of the biosphere; it is global in effect, rivaling or overshadowing natural biogeochemical and evolutionary processes; and many of the impacts are irreversible, certainly on the relatively short time scales of interest to society. Although much more by accident than by design, humanity now controls conditions over the entire biosphere. To list just a few of many impacts, human activity has heavily transformed $40-50 \%$ of the ice-free land surface; ${ }^{23}$ co-opted $50 \%$ of accessible, renewable fresh water; ${ }^{24}$ fully exploited or over-exploited $65 \%$ of marine fish-

17. See, e.g., Global Ozone Research and Monitoring Project, World Meteoro. logical Organization, Report No. 37, Scientific Assessment of Ozone Depletion: 1994 (1995); J.C. Farman et al., Large Losses of Total Ozone in Antarctica Reveal ClOx/NOx Interaction, 315 NATuRE 207 (1985); Mario J. Molina \& F.S. Rowland, Stratospheric Sink for Chlorofluoromethanes: Chlorine Atom-Catalyzed Destruction of Ozone, 249 NatuRE 810 (1974).

18. See, e.g., Bruce E. Tabashnik et al., Global Variation in the Genetic and Biochemical Basis of Diamondback Moth Resistance to Bacillus thuringiensis, 94 Proc. NAT'L ACAD. Scl. USA 12,780 (1997); see generally PAUL R. EHRLICH \& ANNE H. EHRLICH, BETRAYAL OF SCIENCE and Reason: How Anti-Environmental Rhetoric Threatens Our Future 163-65 (1996).

19. See, e.g., Buchmann \& NabHan, supra note 12; Carol A. Kearns et al., Endangercd Mutualisms: The Conservation of Plant-Pollinator Interactions, 29 ANN. REv. EColocy \& Srste.NATICS 83 (1998).

20. See, e.g., Jeremy B. C. Jackson, What Was Natural in the Coastal Oceans?, 98 Proc. NAT'L ACAD. ScI. USA (forthcoming 2001); Daniel Pauly et al., Fishing Down Marine Fooul Webs, 279 Sar. 860 (1998); Janet Raloff, Fishing for Answers: Deep Trawls Leave Destruction in Their Wake-But For How Long? 150 ScI. News 268 (1996).

21. See, e.g., Global Biodiverstty Assessment (Vernon Hilton Heywood ed., 1995); Norman Myers, The Sinking Ark: A New look at The Problem of Disappearing St'ecies (1979); Jennifer B. Hughes et al., The Loss of Population Diversity and Why It Matters, in NA. ture and Human Society 71 (Peter H. Raven ed., 1998).

22. See John P. Holdren \& Paul R. Ehrlich, Human Population and the Global Environment, 62 American Scientist 282 (1974); Peter M. Vitousek et al., Human Appropriation of the Products of Photosynthesis, 36 BioScrence 368 (1986); Peter M. Vitousek et al., Human Domination of Earth's Ecosystems, 277 Scr. 494 (1997) [hereinafter Vitousek et al., Human Domination].

23. Vitousek et al., Human Domination, supra note 22, at 495.

24. Id. at 497. 
eries; ${ }^{25}$ increased the carbon dioxide concentration in the atmosphere by $30 \% ;{ }^{26}$ increased the rate of fixation of atmospheric nitrogen by more than $100 \%$ over natural terrestrial sources; ${ }^{27}$ and driven $25 \%$ of bird species to extinction. ${ }^{28}$

The second reason that ecosystem services are under threat is that natural capital is unrecognized as such by most people. Even when recognized, it tends to be ignored by policy-makers because it is "free." Markets explicitly value and place dollar figures on "ecosystem goods" (such as timber) that are perceived as important and limited in supply. Yet the services underpinning the production of these goods (such as soil maintenance and nutrient recycling) almost without exception have no market value-not because they are worthless or because their interruption is costfree, but rather, because there is no market to capture and express their value directly. Until fairly recently, they were so abundant relative to human demands that such markets were not needed. As a result, no efficient price mechanisms exist to signal scarcity or deterioration of most ecosystem services. A further impediment to establishing markets for most of these services is that, in economic terms, they are classic public goods. Their use cannot be exclusively controlled.

Historically, ecosystem services have been easy to forget and hard to imagine disrupting beyond repair. Recent ecosystem failures, however have attracted public attention. Disastrous flooding in Central America, Venezuela, China, and other places has revealed the critical role of forests in the hydrological cycle-in particular, their role in mitigating flood, drought, and the forces of wind and rain that cause erosion. ${ }^{29}$ The appearance of a dangerous "ozone hole" sharpened awareness of the value of the ozone layer (put there mostly by the work of photosynthetic organisms in the sea some 400 million years ago) in screening out harmful ultraviolet radiation..$^{30}$ Release of toxic substances, whether accidental or deliberate, has revealed the nature and value of services provided

\footnotetext{
25. Id at 495 .

26. Id. at 496 .

27. Id. at 497.

28. Id. at 498 .

29. See Peichang Zhang et al., China's Forest Poligy for the 2Ist Contuny, 288 Scaexce 2135

30. See David Hunter et al. International Environmental Law and Polua $552-55$ (1997) (describing events and negotiations leading to the Montreal Protocol).
} (2000). 
by microorganisms which break down hazardous materials. ${ }^{31}$

\section{To What Extent Do Our Institutions Protect Ecosystem Services?}

In most instances, the political process fails to recognize the value of natural capital. There are few explicit protections for ecosystem services either in domestic or international law. Ironically, our major environmental laws' inability to protect ecosystems is intentional. Legal protection of ecosystems was not a primary objective when the laws were drafted over two decades ago. Generally speaking, our pollution laws (e.g. the Clean Air Act ${ }^{32}$ and Clean Water $\mathrm{Act}^{33}$ ) rely on human health-based standards. Our conservation laws (e.g. the Endangered Species Act ${ }^{34}$ and Marine Mammal Protection $\mathrm{Act}^{35}$ ) are species-specific. And planning under our resource management laws (e.g. the National Forest Management $\mathrm{Act}^{36}$ and Federal Land Policy and Management $\mathrm{Act}^{37}$ ) must accommodate multiple and conflicting uses. Of course, parts of these laws, such as the Clean Water Act's $\$ 404$ wetlands permit program and use of water quality standards, ${ }^{38}$ the Endangered Species Act's critical habitat provisions, ${ }^{39}$ and the National Forest Management Act's use of indicator species such as the spotted owl ${ }^{40}$ clearly can conserve ecosystem services. The point, though, is that these laws were not primarily intended to provide legal standards for conservation of natural capital and the services that flow from it and, as many authors have pointed out, in practice they usually do not. ${ }^{41}$ By contrast, the political process has clearly recognized the value of more traditional forms of capital. Consider the laws and institu-

31. See generally Theo Colburn et al., OUR Stolen Future (1996).

32. 42 U.S.C. $\$ \S 7401-7671$ (q) (1994 \& Supp. IV).

33. 33 U.S.C. $\$ \S 1251-1387$ (1994 \& Supp. IV).

34. 16 U.S.C. $\$ \S 1531-1544$ (1994 \& Supp. IV).

35. 16 U.S.C. $\$ \$ 1361-1407$ (1994 \& Supp. IV).

36. 16 U.S.C. $\$ \$ 1600-1614$ (1994 \& Supp. IV).

37. 43 U.S.C. $\$ \S 1701-1782$ (1994 \& Supp. IV).

38. 33 U.S.C. $\$ 1344$ (1994).

39. 16 U.S.C. $\$ 1533$ (1994 \& Supp. IV).

40. 16 U.S.C. $\$ 1604$ (1994).

41. See David W. Burnett, New Science But Old Laws: The Need to Include Landscape Ecology in the Legal Framework of Biodiversity Protection, 23 Environs EnvtL. L. \& PoL'Y J. 47 (1999); Dianne K. Conway and Daniel S. Evans, Salmon on the Brink: The Imperative of Integrating Environmental Standards and Review on an Ecosystem Scale, 23 SEATTLE U. L. REv. 977 (2000); David R. Hodas, NEPA, Ecosystem Management and Environmental Accounting, 14 NAT. Resources \& ENV'T 185 (2000); Robert B. Keiter, Bejond the Boundary Line: Constructing a Law of Ecosystem Management, 65 U. Colo. L. REv. 293 (1994); J.B. Ruhl, Who Needs Congress? An Agenda for Administrative Reform of the Endangered Species Act, 6 N.Y.U. ENVTL. L.J. 367 (1998). 
tions we have created to protect financial capital. Since the Great Depression, conservation of financial capital has been protected by disclosure laws that ensure investments are preceded by accurate data on the attendant risks, by trusts and estates laws that require trustees to exercise a fiduciary duty on behalf of beneficiaries, and by governmental institutions such as the Federal Reserve and the Treasury Department that support the currency's solvency and promote dependable transactions of financial capital. The overlapping safeguards in place to ensure efficient and predictable financial markets are impressive. Similarly, the emphasis during the 2000 presidential election on education, and the historic struggle during the Great Depression leading to reorganization of the legal relationships between labor and management ${ }^{42}$ testify to the importance given to human capital.

\section{An Ecological-Economic Franework For Managinc Ecosystem Services Within a District}

As we argued in Part II, natural capital is undervalued by the market and under-protected by the law. A focus on ecosystem services provides one means to at least begin to remedy this state of affairs. All things being equal, one would expect policy makers to support the least costly means of providing necessary social services, whether that be safe drinking water or protection from flooding. To identify the most efficient measure requires intelligent costbenefit analyses of both built provision of services and provision through an ESD. Moreover, we must assess the benefits and costs of protecting those services that have no viable alternative, such as climate regulation. Part III describes a framework for making these assessments, as well as the trade-offs involved in ESD design.

\section{A. A Hypothetical District}

To illustrate the issues that arise and the approach that we suggest, we consider the management of ecosystem services in a simplified hypothetical district. This district has three main features, and is portrayed in Figure 1. These features are an upland forest, which provides timber and acts as a watershed; a farmland below, whose irrigation water comes from the forest watershed; and a city,

42. See Dand M. Kennedy, Freedom from fear: The Americin People in Depression AND WAR, 1929-1945 (1999). 
whose drinking water also flows from the forest. A river flows from the forest through the farmland to the city.

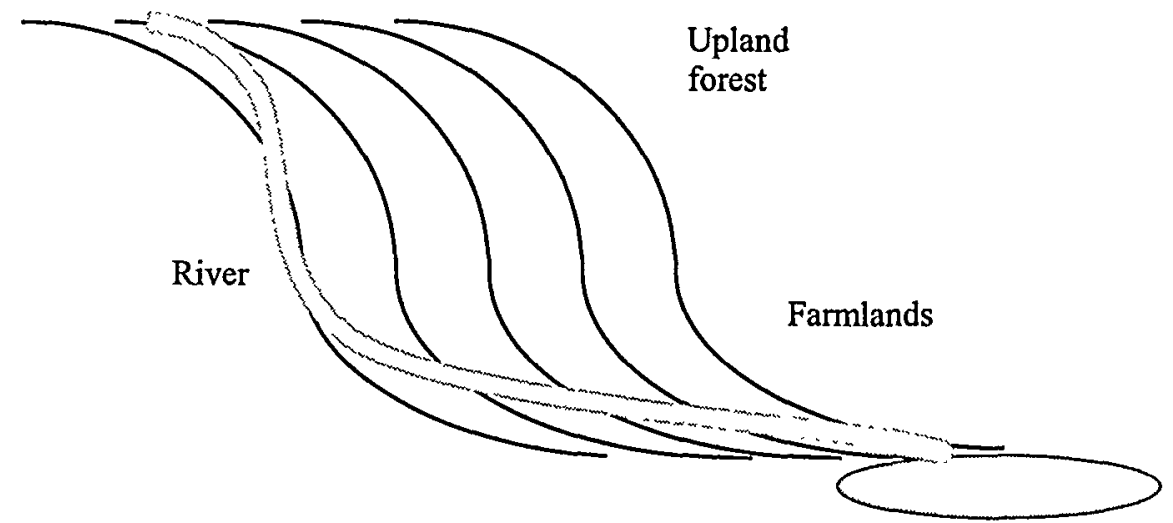

City

FIGURE 1. A hypothetical ecosystem service district.

This system provides the following ecosystem services (see also Table 2): (1) food, (2) timber, (3) climate stability (via carbon storage and sequestration), (4) flood control, (5) pure water, (6) recreation, (7) options for future changes in policies. The role of the last ecosystem service, "options for future changes in policies," is to provide flexibility for the future. For example, we might want to change agricultural policies in the future, or exploit different species. To keep our options open, we would seek to preserve local populations that currently have no commercial value, so that they will be available for possible economics use in the future. The district also provides other services, namely pollination and pest control, which are valued not in their own right but as key inputs to the production of food.

There are, of course, interactions between many of these services-for example, water purification and flood control affect the productivity of agriculture. Table 2 identifies the suppliers and users of several of the services. "Market" here denotes a market operating on a geographic scale larger than that of the district under consideration.

In order to make policy decisions for this district, we must answer three questions. First, what combinations of the seven goods and services can be produced from the land and natural resources in the district? To address this question, we must determine the 
TABLE 2. Suppliers and users of various ecosystem services.

\begin{tabular}{|l|l|l|}
\hline Service & Supplier & User \\
\hline 1. Food production & Farmland & Market \\
\hline la. Pest control & Farmland (set aside) & Farm \\
\hline lb. Pollination & Farmland (set aside) & Farm \\
\hline 2. Timber & Forest & Market \\
\hline 3. Climate stability (C-sequ'n) & Forest \& farmland & Market \\
\hline 4. Flood control & Forest & City \& farms \\
\hline 5. Water purification & Forest & City \& farms \\
\hline 6. Recreation & Forest & City \\
\hline 7. Options & Farmland (set aside) & All \\
\hline
\end{tabular}

tradeoffs among services. For example, how does enhancing the provision of carbon storage, or of timber, affect the production of food, or of recreation or flood control? And how much can technological substitutes for ecosystem services contribute to any of the target outputs? In economic terms, we are asking about the "production functions" for ecosystem services. Second, what are the policy variables that let us attain different combinations of the outputs? For example, what do we have to do to produce more carbon storage and less food? Or more pure water and less timber? What are the levers that move this system? What are the relative values that society places on the different ecosystem goods and services that are available, and how do these values compare to those of other outputs whose generation destroy natural ecosystems (e.g., housing or farmland)?

With tentative answers to the first two questions, we can specify the policy choices that will lead to each of the possible "product mixes." In the final stage of the analysis, we must address the third question: Which of these alternative product mixes is the best for society? This of course cannot be determined just by analyzing the district. For this stage we need to assess society's preferences between the different products, using information about relative valuations. Some of these may be reflected in market prices for the goods or services.

\section{B. Modeling Tradeoffs}

To answer these questions, we have to study the interactions between the provision of the various goods and services, and the consequent rivalries or complementarities between them. That is, 
we must determine how the level of one good or service affects the levels of the others.

Consider first the relationship between the land set aside for the provision of pest control and pollination services, and that used for the production of food. Assume that we are working with crops that require pollination and are vulnerable to insect pests. If all land is devoted to food production (i.e., none is set aside for pest predators or pollinators), there will be less than the maximum possible production of food because there will be little pollination or pest control. A small proportion of land set aside will suffice to shelter sufficient pollinators and pest predators to manage the crop, and this will increase food production; however, at some point, any additional increase in the land set aside for pollination will lead to no further increase in food production and will probably lead to a decrease, since that land is no longer used to produce food. Hence, we have a relationship as depicted in Figure 2.

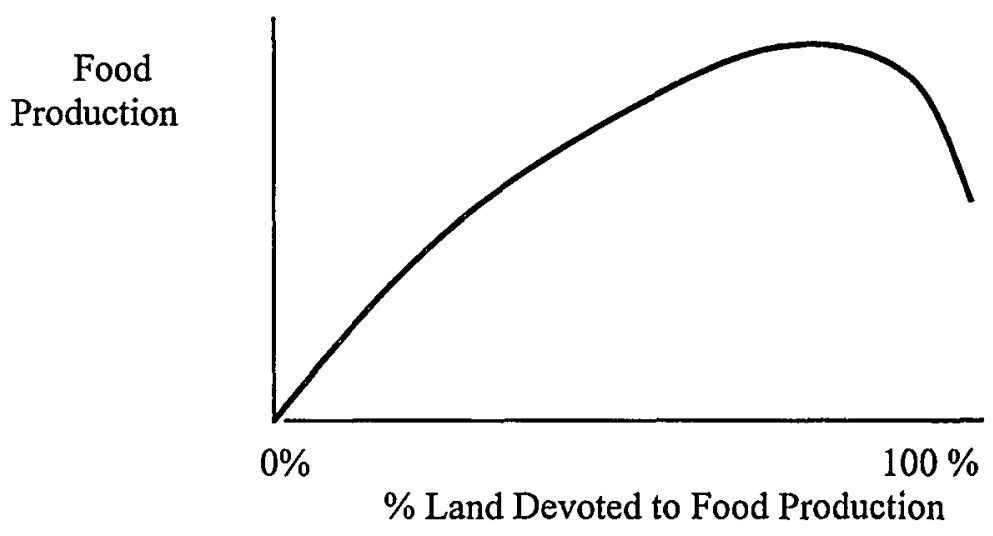

Figure 2. Food production as a function of the percent of land devoted to food production.

In the case of the forest ecosystem, there will be tradeoffs between timber production and other services provided by the forested region, such as recreational services, pure water, and carbon storage. The amount of these other services will probably decline as the extent of timber production rises, so that the tradeoff here may look as shown in Figure 3.

In the case of carbon storage services, there will be a similar relationship, though probably closer to linear, as depicted in Figure 4 (shown as a dotted line because this relationship is particu- 


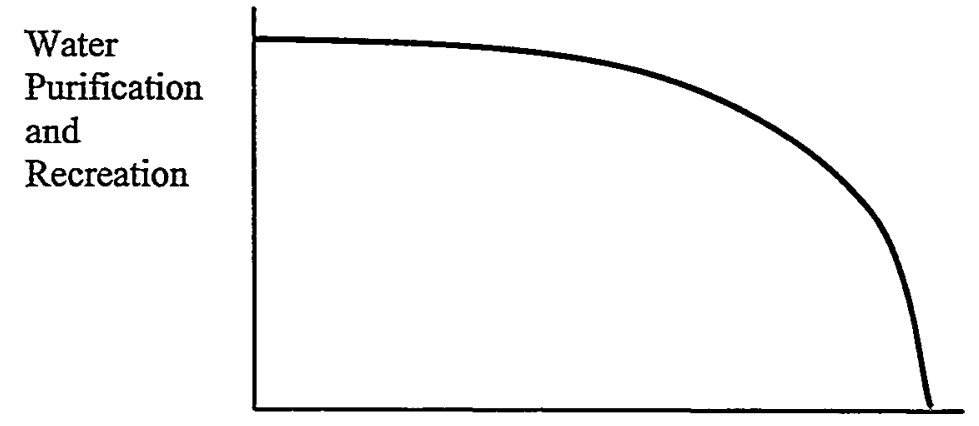

Timber Production

FIGURE 3. Water purification and recreation services as a function of the amount of timber production.

larly sensitive to assumptions about production regime and carbon storage).

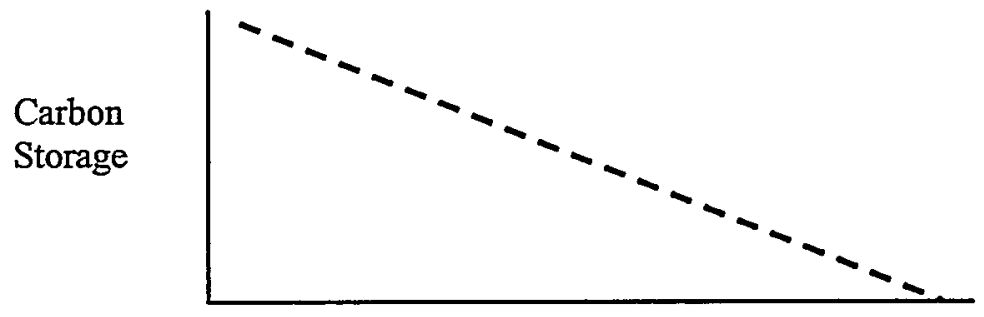

Timber Production

Figure 4. Carbon storage as a function of timber production.

Let us now explore the relationship between option value (the last service listed in Table 2) and the production of food and timber. The possibility of expanding local populations of pollinators and pest predators will be zero if no land is set aside as habitat for them. It is likely, however, to reach a maximum quite quickly as the amount of land set aside increases to some threshold-the minimum amount of habitat need to maintain a viable population. Thus, a little land devoted to habitat for the species will greatly increase the prospects for restoring the species, but additional land will not further increase those prospects. Hence, we have the relationships in Figure 5, which assumes no possibility of outside sources for reestablishment of pollinators and pest predators. Likewise, for the conservation of diversity in the forested area, some 
land must be preserved for old growth but the amount of diversity preserved will rapidly peak as the land set aside for this rises.

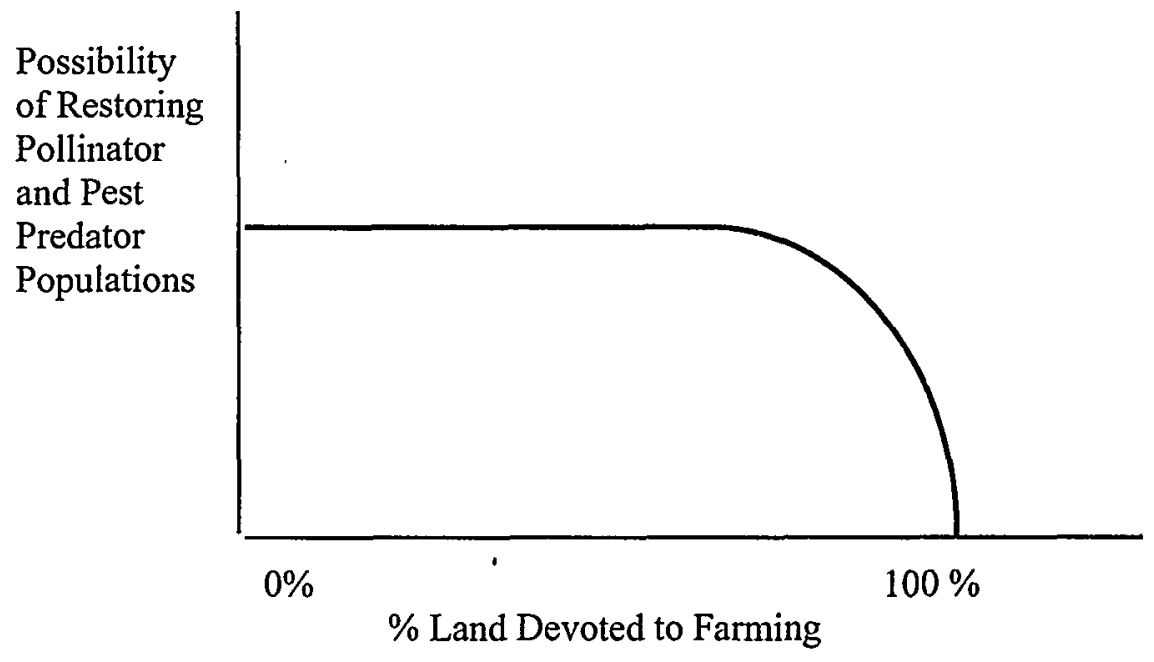

Figure 5. Option value as a function of land devoted to agriculture.

How do we use the information in Figures 2 through 5? Can we construct a single function that describes the relationships between the various possible output mixes? We can, with the concept of a production possibility frontier. Consider a production process that can produce several different outputs from a fixed set of inputs. Then the production possibility frontier does the following: For all different combinations of levels of outputs of all but one of the goods produced, it shows the maximum possible output of that one good. For example, suppose there are two outputs only: water purification and timber. The production frontier shows for any level of timber output the maximum amount of water purification that can be performed.

Figure 6 shows the frontier for three outputs: carbon storage, timber production, and pure water. We assume that maximum timber production results in no carbon storage or water purification, and, conversely, that no timber production maximizes carbon storage and pure water.

The three-dimensional frontier depicted in Figure 6 shows the maximum output of water purification that can be obtained for any combination of levels of carbon storage and timber production. The policy problem is to choose a point on this frontier-i.e. 


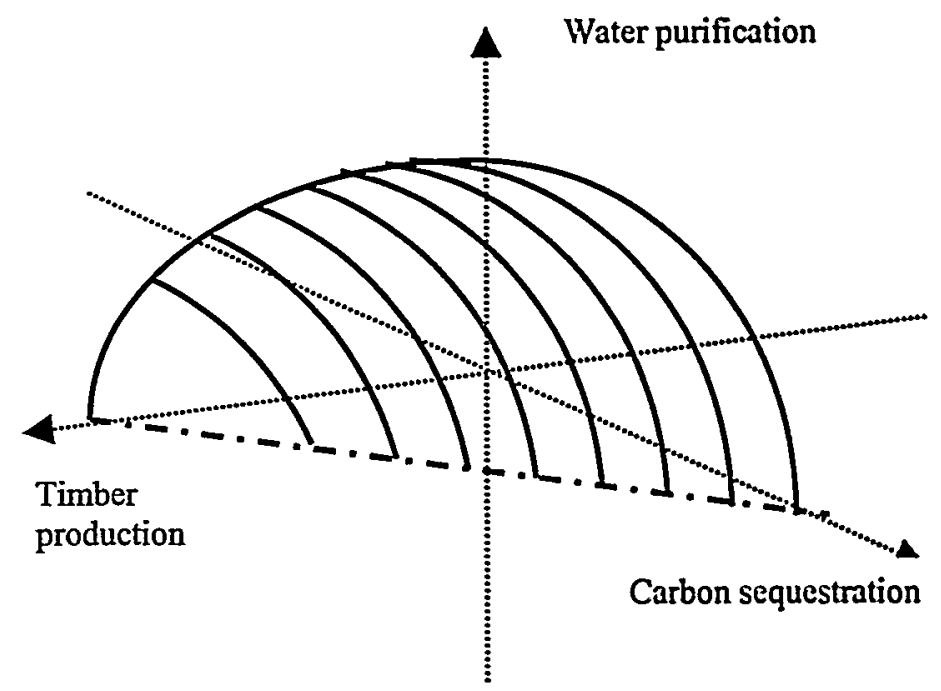

FIGURE 6. A production possibility frontier for three services.

a product mix of the three outputs. Figures 3 and 4 are actually simplifications of Figure 6, with each plot ignoring one of the three services. In fact, the relationship between timber production and pure water in Figure 3 also depends on the level of carbon storage. For example, we might have planted fast-growing trees to maximize storage, which will have an impact on the relationship between timber production and pure water. A complete analysis requires that we spell out these interrelationships between the various activities, and model them all explicitly.

In the context of our hypothetical district, there are seven outputs. Therefore, the overall production possibility frontier is a surface in a seven-dimensional space, $R^{7}$, much more difficult to solve and visualize (obviously) than two or three-dimensional space.

Despite the complexities of the global optimization, one key observation is that the patterns of land use in the forest and on the farms influence the services provided by the district. All seven outputs are affected by these two variables-though they are quite complex variables, incorporating land use and the entire rotation and harvesting patterns in the case of both farms and forest. Consequently, when it comes to providing economic incentives for the provision of any of the ecosystem services, we can use policy measures that encourage the particular uses of farms and forest that lead to the provision of those services.

From an economic perspective, several aspects of these relation- 
ships are important in assessing the policy options. First, are there thresholds in the relationships among some of these variables? Second, are there diminishing or increasing returns to the scale of the processes? A process shows increasing returns if its efficiency rises with the scale of operation, and shows diminishing returns if its efficiency diminishes with scale. The answers to these questions determine whether we can use prices to decentralize decision-making and provide incentives. Prices work best in the case of processes showing diminishing returns. The market mechanism works as a benign invisible hand leading to an efficient allocation of resources if production occurs under conditions of diminishing returns. With increasing returns, concentration and market power generally result, leading to departures from competition and efficiency.

There is a second, simpler way to examine the issues underlying Figure 6. Rather than trying to determine all the tradeoffs between all the different services and then find the best combinations, we can choose several different possible land management strategies and then identify the levels of services that would occur for these particular strategies. For example, we could consider the following five management strategies for the upland region:

(A) convert entirely to pasture;

(B) maintain as mature forest with no harvesting;

(C) adopt sustainable forestry with native species;

(D) conduct unsustainable forestry; and

(E) conduct sustainable forestry with an exotic species.

Figure 7 shows the outputs of four of the seven services (pure water, timber production, carbon storage, and biodiversity conservation) for each of these alternative management strategies for the uplands. The numbers are purely hypothetical, but illustrate possible results. This approach to representing the tradeoffs has the advantage that it can present data on more than three variables. The five management strategies chosen can be thought of as points selected from the overall frontier (as in Figure 6, but seven-dimensional), with the selection criterion being the feasibility of the land management strategy.

In fact, matters are slightly more complex than we have suggested so far, since the manner in which the upland regime is managed will affect the value of agricultural output in the lowland. That is, the choices of management regimes in upland and lowland cannot be independent. Therefore we have to value combinations of the possible strategies. For example, consider upland regimes $A$, converting to pasture, and $\mathrm{B}$, maintaining mature forest with no 


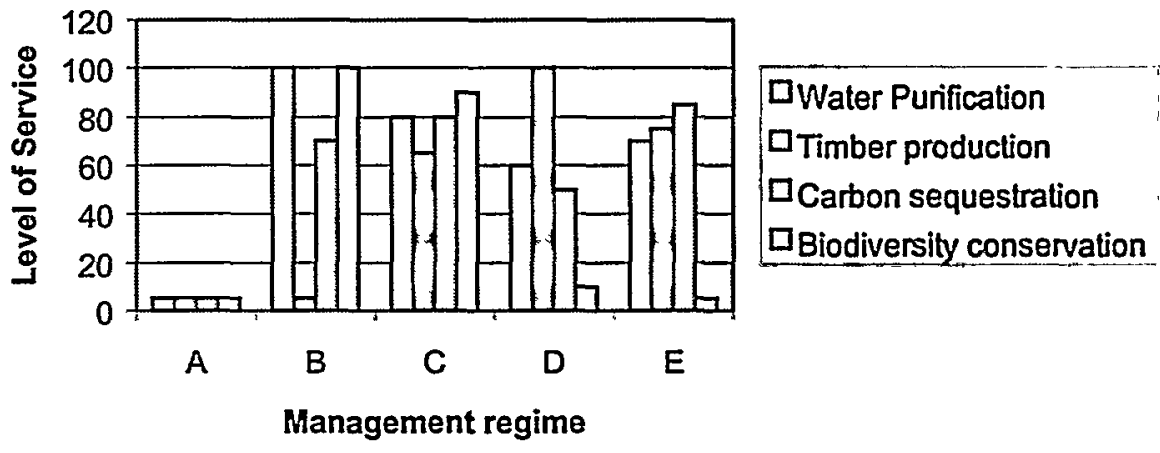

Frgure 7. Service levels for selected upland management regimes. See text for explanation.

harvesting. Converting to pasture will lead to no flood control services and no water purification services being provided, and will therefore affect the food production possibilities of the farmland differently than maintaining mature forest (Regime B). One would expect that food production possibilities under regime $B$ should be higher than under regime $A$. Now let $X$ and $Y$ represent alternative lowland management regimes. $X$ represents a regime in which all land is used to produce a single crop that does require pollination, and $Y$ represents a regime in which some land is kept as semi-natural pollinator and pest predator habitat. There are four possible combinations of the upland and lowland regimes:

(AX) forest converted to pasture, and all farmland utilized;

(AY) forest converted to pasture, and farmland set-asides;

(BX) maintaining forests, and all farmland utilized; and

(BY) maintaining forests, and farmland set-asides.

The levels of three services provided (food, options, and flood control) by each of these four regime combinations are shown in Figure 8. The total output of the management regime $\mathrm{AX}$ is the sum of the upland outputs, the A case in Figure 7, and the associated lowland outputs, the AX case in Figure 8. Similarly, the total output for the management regime $A Y$ is the sum of the outputs for the upland regime A and the lowland regime AX. And so forth. If we had prices for all seven goods and services, we could value the output of all possible combinations of the services for each of the four management regimes. 


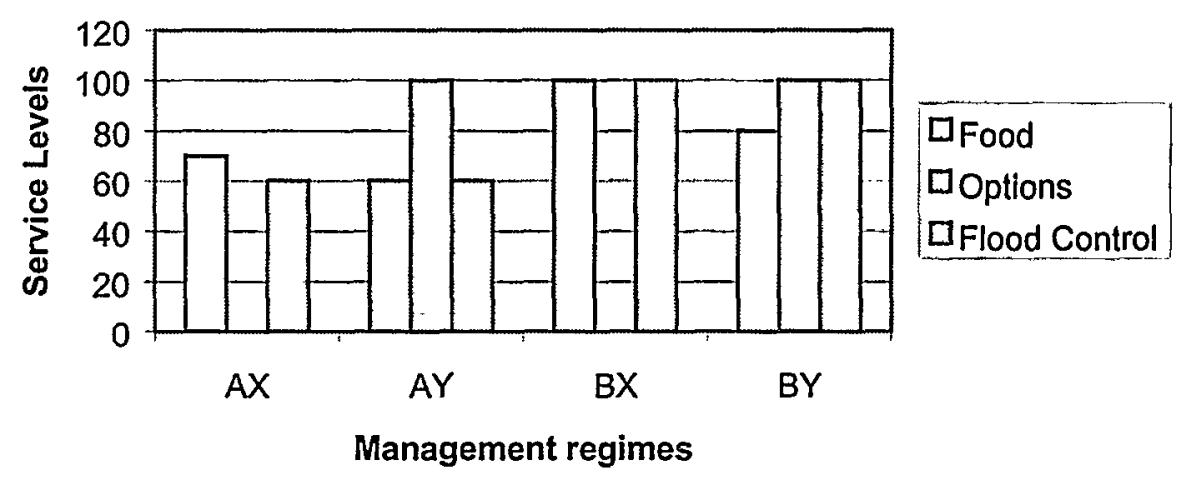

FIGURE 8. Service levels for combinations of upland and lowland management regimes. See text for explanation.

\section{The Optimal Output}

The socially optimal product mix is that mix of outputs that produces the maximum possible value for society from the natural resources that constitute the ecosystem district. This value is measured at "shadow prices," prices that accurately reflect the marginal contribution of each service to society's welfare. The socially optimal output of ecosystem services may or may not involve the production of some particular ecosystem service. Which services and what amount will be produced are determined by the relative prices of those services. For example, if the shadow price of water purification is high, then the optimal product mix will probably contain water purification services. Conversely, if the price of water purification is low, the optimal product mix will probably contain something of even higher value, and water purification will be met by an alternative method that is less costly than the corresponding ecosystem service. Provided the prices used to value all of the outputs are correct, the value of the services provided by the ecosystem and by alternative methods (under the chosen management regime) will be known.

In principle, there are two different ways of finding the socially optimal product mix on the production possibility frontier. One is to describe the frontier mathematically and use information about society's preferences to choose the best point on it. This reduces the selection of the best point to a programming problem or, as illustrated above, to a problem of selection among feasible management regimes.

An alternative, equivalent approach is to present each decision- 
maker in the district with the incentives that would force the system toward an optimal allocation of ecosystem services. In other words, present each farmer and timber producer with a "correct" set of prices for all of the outputs that he or she produces. This means timber producers would face positive prices for carbon storage, water purification, flood control, recreation, and biodiversity support (reflecting the positive externalities they produce). Farmers would face negative prices that reflect the full social costs of using pesticides and fertilizers (i.e., that internalized the negative externalities), thus giving them incentives to preserve pollinators and pest predators. Because the farmers are themselves the beneficiaries of conservation that facilitates pollination and pest services, it may be possible for them to internalize the returns from this function. Indeed, if the prices are chosen to reflect society's valuations, then their profit-maximizing behavior in a competitive market automatically solves the problem of mathematically locating the optimal solution. ${ }^{43}$

In general, the optimal management strategy or set of strategies is the one that maximizes the value of the output of services at shadow prices. In our hypothetical example, the optimal output is that produced by the combination of upland and lowland management regimes that lead to the maximum value of the services produced. The prices used to value the services will be the same whichever method we use to select the best output. Thus, we have identified two approaches and three different methods to determine the management strategy that maximizes the value to society of nature's services.

\section{Legal Analysis of Managing Ecoststeil Services Districts}

In Part III, we explored the ecological tradeoffs among services and discussed the economics of choosing among management strategies to promote services. We now turn to the legal and political challenges in establishing our proposed districts.

The United States has a rich experience with service districts. Throughout the country, local and county government units routinely make on-the-ground management decisions relevant to provision of conservation, drainage, natural resource management,

\footnotetext{
43. This approach is, in essence, the first theorem of welfare economics. Sre grterally Geoffrey Heal, Nature and the Mlarketplace: Gupt'runc the Vill'e of Ecosistem Ser. vCES 21-41 (2000) (describing the importance of externalities to ecosystem senice protection).
} 
erosion control, water supply, and flood control services. ${ }^{44}$ Created either by state statutes or local initiative, these sub-state units exercise substantial authority over local land use decisions and, west of the Mississippi, many water management issues, as well. The powers of these districts vary considerably. For example, under authorization of the Soil Erosion Act of 1935, every state has created soil conservation districts to address soil erosion at the local level. ${ }^{45}$ The typical district has the authority to:

conduct surveys, investigations, and research relating to the character of soil erosion and the preventive measures needed . . . to conduct demonstrational projects in areas subject to erosion by wind or water. . .; to carry out preventive measures, including but not limited to, engineering operations, methods of cultivation, the growing of vegetation, and changes in use of land; to cooperate or enter into agreements with, or to furnish financial or other aid to, any agency, governmental or otherwise, or any person, subject to such conditions as he may deem necessary. . .; to acquire lands, or rights or interests therein, by purchase, gift, condemnation, or otherwise. ... ${ }^{46}$

Such districts may provide useful models for an ESD. As discussed in Part III, the geographic coverage of an ESD is integral to its success, since management regimes in one area are likely to affect services in another. Unless the district exercises some control over the habitat generating an ecosystem service, it cannot ensure efficient or adequate provision of the service. For example, an ESD along the Mississippi River in Missouri would not be able to control the provision of flood control or water purification services adequately because of the vast watershed areas outside of its jurisdiction in upstream states.

As a matter of institutional design, the limited jurisdiction of local districts can pose a considerable challenge. In general, political jurisdictions are not closely aligned with naturally demarcated areas such as watersheds, exercising authority instead over politically bounded areas as defined by municipal, county, or state lines. A small number of interstate initiatives, such as the Chesapeake Bay Initiative, have sought to better align political actors within the

44. See William Goldfarb, Watershed Management: Slogan or Solution? 21 B.C. ENvTL. Aff. L. Rev. 483, 496 (1994) (citing Charles J. Meyers et al., Water Resources Mhnacement: A Casebook on Law and Public Policy 731-70 (1988)); see also Larry C. Frarey, Ron Jones \& Staci J. Pratt, Conservation Districts as the Foundation for Watershed-Based Programs to Prevent and Abate Polluted Agricultural Runoff, 18 Hamline L. Rev. 151, 158 (1994).

45. 16 U.S.C. $\$ 590$ (a) (1994).

46. $I d$. 
natural ecosystem boundaries. ${ }^{47} \mathrm{~A}$ number of states have also aligned political and natural boundaries within their state jurisdictions, as in the cases of the New Jersey Pinelands Commission ${ }^{48}$ and the Adirondack Park Agency of New York. ${ }^{49}$ But such instances are rare.

In addition to overlapping geographic jurisdictions, the interactions of overlapping substantive jurisdictions are critical to the legal control of natural resources. For example, water resource issues are overseen by 13 different congressional committees and subcommittees, 8 cabinet agencies, 6 independent regulatory agencies, 2 White House offices, 200 state departments, and approximately 100,000 local entities. ${ }^{50}$ Flood control is managed at the federal level by the Bureau of Reclamation, by states in interstate compacts, and within states by local flood districts. As a matter of coordination, the larger the number of political entities required for a decision, the greater the costs of collective action and, therefore, the less likely action will be taken. All other things being equal, those ecosystem services requiring larger areas for their provision-and hence involving more political entities-will prove more difficult to administer.

As noted above, soil conservation districts throughout the country already have broad-ranging authority, from developing conservation plans and conducting research, to entering into contracts and purchasing land. To operate effectively, ESDs will require a similar range of legal powers, in some cases more extensive than those in soil conservation districts. The least controversial power is the authority to generate information. For example, existing districts could be mandated by state legislatures to explicitly compare the cost of service provision through both natural and built means. This approach also mirrors many of the regulatory reform proposals in Congress since 1995 that mandate more transparent and inclusive cost-benefit comparisons. This type of reflexive mandate would force at least minimal consideration of service provision by ecosystems. ${ }^{51}$ Mandating districts to pay closer attention to provi-

47. See Goldfarb, supra note 44 , at 494 (citing T. Hortox \& W. M. Eranau'M, Turs:ing The Tide: Saving Chesapeake Bay (1991)).

48. N.J. Star. ANN. \$ 13:18A-8 (West 1993).

49. N.Y. Law $\$ 24-0805$ (McKinney 1997); sea also Goldfarb, supra note 44 , at 496 (citing Helen M. Ingram, The Political Economy of Rrgional Water Institutions, 55 AMer J. Agr. ECON. 10 (1973)).

50. Goldfarb, supra note 44 , at 485 .

51. See Eric W. Orts, Reflexive Envirommental Laxu, 89 Nw. U. L. Rev. 1227 (1995). 
sion of services by ecosystems does not, of course, require rejection of human intervention.

ESDs could also play a coordinating function across districts Because district jurisdictions rarely track ecological or watershed boundaries, efforts in one district to enhance ecosystem services can be weakened or, in some cases, frustrated by activities in another district working at cross-purposes. One district's management for natural pollination, for example, can be nullified by a neighboring district's spraying of pesticides on crops and adjacent lands. Information exchange among ESDs could result in better-coordinated actions or, at a minimum, highlight counterproductive activities.

More controversially, ESDs could be granted zoning authority or other land use powers (such as condemnation). The grant of such authority would, however, require transferring that power from its current source (unless the ESD acted concurrently with the zoning authority) and no doubt could threaten certain vested interests. Finally, the ESD might be granted taxation authority. Taxes could provide funds to pay for condemnation and, through charges and subsidies, facilitate the movement toward the optimal allocation of services through pricing. ${ }^{52}$

The various powers listed above may be found together in municipal governments but are rarely found together in districts. The majority of the more than 6,000 soil conservation districts, for example, do not have powers of taxation or condemnation. Authority to regulate land use is not uniform, either. ${ }^{53}$ Thus from both environmental and economic efficiency perspectives, single coordinated districts aimed at the production of mixed services would be significantly outside the historical norm. In many cases, then, creation of ESDs may resemble a zero-sum game. Concentrating legal powers such as condemnation or taxation authority in an ESD may require removing them from existing political bodies. The argument for such a transfer of power will be greatly strengthened by pointing to successful examples of operating ESDs. Part V explores how to move from theory to practice and create such precedents.

(describing the range of reflexive policy instruments in environmental law that generate information).

52. See discussion supra Part III.C.

53. See John H. Davidson, State Soil Erosion Control Laws, Conservation Plans and Nonpoint Pollution, I Great Plains Nat. Resources J. 421, 423-24, 440 (1996); Dean T. Massey, Land Use Regulatory Power of Conservation Districts in the Midwestern States for Controlling Nonpoint Source Pollutants, 33 Drake L. Rev. 35, 51, 56-68 (1983-84). 


\section{Priortties for Putting Theory of Ecosystem Service Districts into Practice}

The preceding sections have set out the ecological, economic, and legal issues raised by the creation of ESDs. This section explores how to move from theoretical analysis to practical application.

\section{A. Characterizing the Production Functions of Ecosystem Services}

The first step in creating Ecosystem Service Districts involves identification of the services. In comparison to record keeping of physical and financial capital, little attention has been paid to the stocks of natural capital that supply ecosystem services. A systematic, quantitative cataloguing of the sources and consumers of ecosystem services is necessary to institute ESDs. For any given location, decision-makers need to know which services are produced and consumed locally (e.g., pollination, pest control, renewal of soil fertility), which regionally (e.g., seafood, timber, flood control, water purification), and which globally (e.g., preservation of the genetic library, climate stabilization). At its most ambitious, this would require classifying and mapping the United States according to ecosystem type and land use, starting at the district level, and ultimately creating a national assessment of the ecosystem services that flow from our natural capital.

Once the major service types and flows are identified, their ecological and economic (and possibly other) attributes must be determined. While a great deal is known about the functioning of ecosystems and the supply of services in general terms, there is a paucity of information on particular local ecosystems and economies. An ecological characterization of ecosystem services is needed to inform decision-makers, prior to any attempt to value the services, of the ecological trade-offs associated with alternative courses of action. Ecological characterization would determine the shapes of the production functions describing how ecosystems generate services. ${ }^{54}$ In other words, it would illuminate the relation between the level of services (quantity and quality) supplied by an ecosystem and its geographic extent, as well as the type and degree of human modification of the ecosystem. For instance, an ecological characterization of the hydrological services supplied by a forest

54. HaL R VARIAN, Mrcroeconomic ANalysis 1-21 (1978) (describing the use of production functions). 
catchment would describe water flow and quality as a function of forested area and the type and level of human activities in and around the catchment.

Because ecosystem services are highly interdependent, ecological characterization would also illuminate how exploiting or impairing one service would influence the functioning of others. For the same forest catchment, one would specify which combinations of services and human activities-and what levels of each-could be sustained. Ecological characterization would also determine the extent, and time scale over which, the ecosystems supplying particular services are amenable to repair. Anticipating the responses of ecosystems to perturbation is essential in establishing sound policy, yet such responses are poorly understood. ${ }^{55}$

Ecosystem services also need to be characterized in an economic context. Very little is known about marginal values (the net benefit or cost associated with protecting or destroying the next unit of an ecosystem) or about the nonlinearities in ecosystem responses to human impact. Economic characterization would identify the social benefits and costs associated with alternative ways of managing ecosystem assets. It would also aim to determine how individual preferences for alternative options can be fairly aggregated, and how the costs and benefits of alternative schemes can be fairly distributed. A high degree of accuracy will be unnecessary in many cases since, from a policy perspective, the most important valuation decisions will be those where the benefits greatly outweigh costs, and vice versa. Further development of such assessments would define the envelope of opportunities and limitations in applying the ecosystem services framework, illuminating how general the findings are from specific localities, and serving as a guide to policy development.

\section{B. Mapping Ecosystem Services}

The second step in implementing Ecosystem Service Districts is to map out ecosystem "service areas." The process of mapping biodiversity and its threats has been essential to establishing, and acting upon, priorities for nature conservation. ${ }^{56}$ By contrast, neither general priorities nor a methodology for establishing them have been developed systematically for ecosystem services. Ecosystem

55. Gretchen C. Daily et al., supra note 2, at 395-96.

56. See, e.g., Taylor H. Ricketts et al., Terrestrial Ecoregions of North America: a Conservation Assessment (1999). 
"service area" maps that would locate suppliers, consumers, and threats relevant to each service are urgently needed but virtually non-existent. ${ }^{57}$ They could be used in the same way that maps of species or ecosystem distributions are used to determine their associated threats to persistence. ${ }^{58}$

The mapping process could illuminate three crucial types of information: First, it would reveal the levels and types of services that could be supplied under alternative land management regimes, as outlined in Section III. Second, it would indicate the degree of spatial congruence in the supply of different services. Imagine, for instance, that native habitat is required for each of four key services in an area: flood control, water purification, pollination, and conservation of options. Then the mapping process would reveal the overlap in the optimal allocation of land to each service; i.e., whether the optimum land management regime to achieve a desired level of flood control would serve well (or poorly) in supplying the other three services. Finally, the mapping process could have an important dynamic component, forecasting changes both in services, and in societal need for them, under alternative future scenarios of demographic, land-use, and climatic change. ${ }^{59}$

Natural water purification is a good service with which to begin mapping efforts, as it has a scientific and regulatory basis sufficiently substantial to (i) define criteria for prioritization, and (ii) apply these geographically to determine both the scope for using ecosystem approaches to water purification and the places that merit the most attention and effort. The mapping process would also provide a focus around which to involve stakeholders, integrate social and ecological aspects of ecosystem service management, experiment with innovative incentive and financing schemes, and advance the policy agenda. ${ }^{60}$ This focus has proven especially useful in catalyzing the implementation of ecosystem approaches in Australia. ${ }^{61}$

57. Patricia Balvanera et al., Conserving Biodirensity and Ecosysten Services, 291 Scaevce. 2047, 2047 (2001).

58. See, e.g., TAYLoR H. Ricketrs Et AL, supra note 56.

59. Patricia Balvanera et al., supra note 57, at 2047-48.

60. See Gretchen C. Daily, Management Objectizes for the Protedion of Ecosystem Senvices, 3 ENvTL Sct. \& PoL'y 333, 337-38 (2000).

61. Gretchen C. Daily, personal observations, April 3-14, 2000, tour of watersheds in Australia implementing ecosystem approaches to maintaining water quality. 


\section{Transitioning Toward a System of Ecosystem Service Districts}

Clearly, there exists no uniform optimal mix, or level, of ecosystem service production for all districts. The environmental demands and impacts of human societies are ever shifting, and require flexibility and options in the supply of services. Thus, as described in the preceding sections, an explicit accounting of ecosystem services and the impacts of alternative courses of action on those services is a critical first step to informed decision-making. At present, many would argue that the level of uncertainty in our understanding of ecological processes, together with the prevalence of nonlinearities and irreversibilities, calls for invoking the precautionary principle. ${ }^{62}$ According to this principle, it would be prudent to avoid courses of action that involve possible dramatic and irreversible consequences and wait for better information before putting ecosystem capital at great risk. In the meantime, we need to identify the main sources of uncertainty regarding the protection of ecosystem services, and their relative importance. Developing methods of quantifying this uncertainty, and incorporating it into flexible districts-oriented policy, while challenging, is key.

The institutional mechanisms appropriate for protecting ecosystem services are likely to vary considerably with ecological and social context. Management districts provide an institutional framework for acquiring essential locally based information. Ecosystems, however, are idiosyncratic and the devil is in the details, so that what holds true in one region may not apply well elsewhere. For instance, certain species perform keystone roles in some ecosystems, but play minor roles in others. ${ }^{63}$ In some cases, protection of a relatively well-understood or valued service could confer protection on other services when there is little understanding or institutional support to bring about their protection directly (known as the "umbrella" effect in conservation). ${ }^{64}$ In this way, the interdependence of services might be exploited to maximize the benefits of protecting a single service. In theory, then, poorly known pollination services might be protected in farmed, hilly regions by ensuring that erosion control measures used native vegetation (to (1996).

62. See, e.g., HunTER ET AL., supra note 30, and sources cited therein.

63. See Mary E. Power et al., Challenges in the Quest for Keystones, 46 BioSCIENCE 609

64. See generally, James Salzman and Juge Gregg, Ecosystem Services and the Exxon Valdez Restoration, in James Salzman et al., Improved Ecosystem Management Through Ecosys. TEM Service Valuation (forthcoming EPA report, 2001); Gretchen C. Daily et al., supra note 2. 
serve as habitat for pollinators). This need for coordination is a further argument for the creation of districts.

To foster the implementation of ESDs, we suggest four useful steps. First, pick the low-hanging fruit: Assess the ecological, economic, and social justifications for establishing safeguards for comparatively well-known ecosystem services (such as water purification and flood control, where certain types of market institutions already exist; and for carbon storage, where a market may be emerging). Depending on local circumstances, many of these services may be "bundled," so that protecting one service (such as flood control) protects other services (such as biodiversity or water purification). Second, learn vicariously. Monitor carefully the outcome of efforts to safeguard ecosystem services, both in the United States, and internationally. The compilation of such experience could inform discussions about what works and doesn't work, and why it works or not. Third, experiment and innovate. There could be great payoffs for fostering small-scale, experimental efforts to safeguard less appreciated but valuable ecosystem services. These efforts could be overseen by management districts. Fourth, promote models of success. Many aspects of ecosystem service management could be implemented in the existing legal and economic framework, with institutional mechanisms that have proven very successful in the communities where they have been implemented.

\section{Conclusion}

Without appropriate institutions, notice from ecologists, economists, and lawyers that ecosystems provide important and valuable assets will do nothing. However, as described in the Introduction ${ }^{65}$ to this issue of the Stanford Environmental Law Journal, there are reasons for optimism. Promising new institutions for safeguarding ecosystem services are emerging in a wide array of cultures and economies-from Australia, Costa Rica, and Madagascar ta the United States and Vietnam-and on a variety of scales-from local to international, and in government, NGO, and private sector contexts. $^{66}$

65. Salzman et al., supra note 4 , at $315-16,329$ app.

66. See Gretchen C. Daily et al., supra note 2; Salzman et al., supra note 4, at 322-26. The services safeguarded by these emerging institutions include pollination; pest control; water supply for drinking, for irrigation, and for hydropower generation; maintenance of soil fertility, sustainable harvesting of tropical timber; provision of aesthetic beauty; and even decomposition (of orange peels produced by Del Oro, an orange juice company in Costa Rica-a service provided by allowing their deposition in a regional national park). 
Despite the challenges described throughout this article, the United States could, given sufficient political will, design and implement effective ESDs. Mindful of the damage from flooding along the Mississippi, a Mississippi Valley Authority, for example, might be charged with coordination of land use policies throughout the watershed to ensure provision of flood control and water purification services. ${ }^{67}$ This institution would, with local and regional involvement, consider the trade-offs and benefits in providing natural rather than built services. In practice, it might resemble a hierarchy of ever-larger ESDs, depending on the geographic scope of service provision. Such an approach has obvious benefits over the current fragmented and inadequate institutional structure, but we obviously do not anticipate a series of ESDs springing up across the nation tomorrow. Our current political structures do not, with rare exception, manage the provision of natural services. Inertia, vested economic interests that profit from the sale and maintenance of built provision of services, ignorance of the benefit provided by natural systems, scientific uncertainties, political institutions with inadequate substantive and geographic authority, and institutions that would lose power with a focus on services all contribute to our failure to establish ESDs.

If one considers the modern era of environmental law, though, there has been a clear trend of sweeping legislation following highprofile environmental disaster. Reforms often occur when the national spotlight uncovers the failure of current institutions and protections. The Comprehensive Environmental Response, Compensation, and Liability $\mathrm{Act}^{68}$ (popularly known as "Superfund"), for example, was passed following the national uproar after the discovery of contaminated soil in Love Canal, New York. While we clearly do not hope for flooding events, degraded water quality and other ills, such problems may, in time, provide a wake-up call and focus public attention on the protection of services. Building the political constituency to demand a services approach, however, requires more than bad weather and misfortune.

Rene Castro et al., The Costa Rican Experience with Market Instruments to Mitigate Climate Change and Conserve Biodiversity (1998); see also Katherine Eluison \& Gretchen C. Daily, Green Gold: The Quest to Make Conservation Profitable (forthcoming Spring 2002).

67. Geoffrey Lean, The Year of the Flood; Rising Waters are Causing Unprecedented Death and Desiruction. And Humanity Must Share the Blame, THE INDEPENDENT (LONDON), November 15, 1998, at 26 .

68. 42 U.S.C. $\$ \S 9601-9675$ (1994 \& Supp. IV). 
The importance of ecosystem services and how they are provided must be much better understood by the general public.

Building the necessary political constituency for a transition to administrative structures to protect ecosystem services will require far more than the scientific community's current educational efforts and academic publications. ${ }^{69}$ The relative success of the Intergovernmental Panel on Climate Change (IPCC) in keeping the public and governments informed about the state of the climate, the consequences of different patterns of change, and the possibility for ameliorating changes for the worse could provide a model to encourage the development of administrative structures like ESDs for the preservation of natural capital. In the United States, establishment of a federal Interstate Panel on Ecosystem Capital could begin to promote (and perhaps fund) the sorts of activities listed above in Part IV. It could involve environmental scientists, resource managers, attorneys, state officials, concerned business firms, NGOs, and representatives of the general public in transparent investigations and discussions of the ways to capture and control the social benefits of the nation's ecosystem endowment. If successful, it could provide a model for similar institutions in other nations, and perhaps feed back positively to enhance the activities and influence of the IPCC and other institutions necessary to protect international public goods. In fact, efforts to this end are already underway internationally. The Millennium Ecosystem Assessment aims to provide the first global appraisal of the condition and future prospects of ecosystems, and to build local and global capacity for evaluating the complex tradeoffs involved in managing ecosystems for societal benefit. ${ }^{70}$

69. See, eg., The Ecological Society of America and the Union of Concerned Scientists, The Ecosystem Services Communication Project, at http://esa.sdsc.edu/ecosenices.hum (last visited March 19, 2001). The goals of the project are described as follows:

The goal of the ESA/UCS Ecosystem Services Communication Project is to use the concept of ecosystem services-especially those that provide tangible bencfits to humans-to mobilize the scientific community in raising the public's awareness of the importance of our biological resources. The specific objectives are: (1) to develop a set of outreach tools on specific ecosystem services designed for use by scientists and other professionals to inform the public and policgmakers about the importance of maintaining healthy ecosystems and protecting biodiversity; (2) to develop strategies and put into action an outreach and distribution plan for disseminating this information. Id.

70. See Edward Ayensu et al, Intemational Ecosystem Assessnenl, 286 Scievce 685-86 (1999). 
[Vol. 20:333

The task seems daunting, but perhaps Americans can take hope from their history. In 1760, the British colonies in North America were a diverse and squabbling group held together primarily by their ties to the Crown. In 1790, thirteen of them were a new nation with an extraordinary Constitution that has endured for more than two centuries. All that came about without benefit of phones, television, fax machines, or even the Internet, based simply on a shared belief that there should not be taxation without representation. ${ }^{71}$ In the context of the day, the challenge to the colonists was fully as great as that of saving the systems that support our lives is to us today. The diversity of views and interests among the actors, and the arguments about the righteousness and importance of the cause, and the possible courses of action, were just as heated. But the colonists overcame the differences and the odds and got the job done in less than three decades with few of the advantages for the sharing of knowledge that we possess today. They created the political will to succeed; we need to do the same.

71. See generally Edmund S. Morgan, The Birth of the Republic 1763-89 (3rd ed., 1992). 